\title{
OBJEKTIVIKASI PEREMPUAN TUA \\ DALAM FOTOGRAFI JURNALISTIK \\ Analisis Semiotika pada Foto-Foto Pameran Jalan Menuju Media Kreatif \#8
}

\author{
Sigit Surahman \\ Dosen Program Studi Ilmu Komunikasi, FISIP, Universitas Serang Raya \\ Jalan Raya Serang-Cilegon Km. 5 (Taman Drangong), Serang, Banten \\ No. Hp.: 087771297819, E-mail: saleseven@gmail.com
}

\begin{abstract}
Abstrak
Penelitian ini berfokus pada objektivitas perempuan tua dalam fotografi jurnalistik. Objektivikasi perempuan adalah objek yang menarik karena menjadi sebuah fenomena dalam kehidupan masyarakat. Hampir di setiap media massa, perempuan diposisikan sebagai pelengkap dunia laki-laki. Paras cantik dan keindahan lekuk tubuh perempuan dijadikan sebagai objek seksual. Lain halnya dalam karya fotografi pada pameran "Jalan Menuju Media Kreatif \#8". Dengan analisis deskriptif interpretif berparadigma kritis, penelitian ini bertujuan mendeskripsikan dan menginterpretasikan data yang bersangkutan dengan objektivikasi dan mitos dalam karya fotografi jurnalistik. Variabel penelitian ini adalah fotografi jurnalistik, perempuan, dan komunikasi visual. Terdapat tiga objektivikasi perempuan dalam karya foto jurnalistik ini: pertama, objektivikasi perempuan terletak pada inner beauty; kedua,; perempuan menikmati pekerjaannya sebagai ibu rumah; dan ketiga, perempuan tampil tanpa make up tebal. Mitos kecantikan perempuan terletak pada inner beauty, dalam foto-foto ini disajikan melalui keaslian wajah, profesi, dan ketaatannya. Mitos lain adalah penempatan perempuan yang selalu di wilayah domestik. Dengan demikian, perempuan tidak lagi hanya menghabiskan waktunya untuk berdandan dan bergaya.
\end{abstract}

Kata kunci: objektivikasi, fotografi,feminisme, komunikasi visual

\section{Abstract}

Objectification of Elderly Women in Photojournalism: Analysys of Semiotics on the Photographs of 'Jalan Menuju Media Kreatif \#8'. This study focused on elderly women objectivity in photojournalism. The objectification of women is an interesting object because it has become a phenomenon in the society. Almost in every mass media, women are positioned as the complement of men's worlds. Pretty faces and the beauty of women's curves are made as sexual objects. There was a difference in the photography exhibition in the event of "Jalan Menuju Media Kreatif \#8". By using interpretative descriptive analysis with critical paradigm, this research aims to describe and to interpret the data related to the objectification and myths in the photography works of photojournalism. The variables of this research are photojournalism, women, and visual communication. There are three objectifications of women in those works of photojournalism; first, objectification of women on their inner beauty; second, women enjoying their work as homemakers; and three, women without thick make-up. The myth of female beauty lies in the inner beauty, therefore in the photographs they were represented through the authenticity of their faces, professions, and obediences. Another myth is the position of women in the domestic sphere. Thus, women did not just spend their time to dress up and to be stylish.

Keywords: objectification, photography, feminism, visual ommunication

\section{PENDAHULUAN}

Dalam kehidupan sehari-hari banyak media menyiarkan tindak ketidakadilan yang dialami oleh kaum perempuan. Banyaknya media massa yang mempertontonkan perempuan sebagai objek yang menarik terlepas dari segala yang dialami. Mulai dari prestasi, kecantikan, bahkan ketidakadilan yang menimpa perempuan menarik untuk disiarkan secara luas. Hal semacam ini menjadi sebuah fenomena dalam 
kehidupan masyarakat maupun dalam bentuk pemberitaan media massa. Tidak jarang, hampir di setiap media massa perempuan diposisikan sebagai pelengkap dunia laki-laki, paras cantik, dan keindahan lekuk tubuh perempuan dijadikan sebagai objek seksual.

Pornografi merupakan salah satu bentuk objektivikasi perempuan di media massa. Pornografi adalah gambar-gambar pencabulan yang dapat diperoleh dalam bentuk foto dan gambar video (Bungin, 2008). Banyaknya kasus pelecehan seksual, perkosaan, dan kekerasan seksual lainnya di masyarakat ditengarai disebabkan semakin maraknya pornografi, dan perempuan juga yang menjadi korban utama dalam kasus kejahatan seksual tersebut.

Stereotype berbagai media massa selalu menempatkan bahwa perempuan harus selalu tampil menarik, cantik, sempurna, dan seksi untuk bisa dengan mudah memikat lawan jenis. Hal ini semakin kuat dengan adanya kecenderungan perempuan saat ini yang cenderung suka memamerkan kecantikan paras dan keindahan lekuk tubuhnya. Erotisme perempuan dijadikan oleh media massa sebagai kecenderungan dalam pemberitaan ketika media kehilangan idealisme dan mulai merasa terancam gulung tikar karena persaingan antarmedia massa, ketika media baru mulai memosisikan dirinya di masyarakat dan ketika masyarakat mulai membutuhkan pemberitaan erotisme (Bungin, 2008).

Dewasa ini objektivikasi terhadap tubuh perempuan telah menyebar luas di masyarakat dalam berbagai macam bentuk dan dapat diperoleh dengan mudahnya melalui berbagai jenis media, salah satunya media cetak antara lain; surat kabar, tabloid, baliho, poster, majalah, dan sebagainya.

Sebuah perspektif yang berbeda dalam memosisikan perempuan dilakukan oleh beberapa fotografer melalui bidikan lensa.
Salah satunya yang dilakukan oleh Fakultas Seni Media Rekam melalui Pameran Seni Media Rekam "Jalan Menuju Media Kreatif \#8". Pemeran ini merupakan program tahunan yang sudah diselenggarakan sejak tahun 2009 dengan mengangkat tema yang selalu berbeda setiap tahunnya. Kegiatan pameran ke-8 ini diikuti oleh dosen dan mahasiswa Fakultas Seni Media Rekam, ISI Yogyakarta, anggota BKS-PT Seni Indonesia, perwakilan dari perguruan tinggi seni luar negeri, dan fotografer profesional se-Indonesia.

Fotografi merupakan salah satu media komunikasi visual. Komunikasi visual merupakan kegiatan komunikasi yang menggunakan unsur rupa (visual) pada berbagai media, baik percetakan, papan reklame, televisi, film /video, internet dan lain-lain, dua dimensi (2D), maupun tiga dimensi (3D), baik yang statis maupun bergerak (time based). Fotografi merupakan salah satu komunikasi visual yang juga dapat menciptakan dan memvisualkan secara jelas buah pikiran dan tulisan-tulisan yang dibuat oleh seorang fotografer ketika membuat karya foto jurnalistik. Fotografi menjadi bagian yang teramat penting dalam berbagai bentuk kegiatan komunikasi karena karya foto sering kali tidak bisa digantikan oleh gambar atau bentuk ilustrasi lainnya.

Dalam pameran ini terdapat empat karya fotografi yang mengambil objek perempuan tua sebagai sebuah karya eksotis penuh makna. Karya-karya tersebut di antaranya: (1) karya Ang Giok Bing dengan judul "Mencuci”, (2) karya Stephanus Setiawan dengan judul "Pengasapan Ikan", (3) karya Ajie Lubis dengan judul "Smile", dan (4) karya John Tefon dengan judul "Khusuk". Dari sekian banyak karya foto dalam pameran ini, keempat foto tersebut menjadi yang paling menarik untuk dijadikan objek penelitian 
dengan analisis semiotika Roland Barthes karena mengambil perspektif yang berbeda dari kaum perempuan melalui bidikan lensanya.

\section{METODE PENELITIAN}

Metode yang digunakan dalam penyusunan artikel hasil penelitian ini adalah metode penelitian deskriptif interpretif berparadigma kritis. Metode penelitian ini bertujuanmendeskripsikan,menginterpretasikan, dan menuturkan data yang bersangkutan dengan karya fotografi jurnalistik melalui studi kepustakaan, baik dari buku, jurnal, maupun referensi lain yang mendukung penelitian yang kemudian dianalisis lebih mendalam.

\section{LANDASAN TEORI}

\section{Fotografi Jurnalistik}

Kata fotografi berasal dari kata photo yang berarti cahaya dan graph yang berarti gambar. Dalam Kamus Ilmiah Populer disebutkan bahwa photo adalah gambar dari hasil kerja kamera. Sementara itu, fotografi adalah pengetahuan teknik pengambilan gambar dengan kamera (Partanto \& Drahlan Al-Barry, 1994).

Jurnalistik atau journalisme berasal dari perkataan journal, artinya catatan harian, atau catatan mengenai kejadian sehari-hari, atau bisa juga berarti surat kabar. Journal berasal dari perkataan Latin diurnalis, harian atau tiap hari. Dari perkataan itulah lahir kata jurnalis, yaitu orang yang melakukan pekerjaan jurnalistik. Foto jurnalistik merupakan sajian gambar atau foto yang dapat berdiri sendiri sebagai visualisasi suatu peristiwa. Foto jurnalistik juga dapat melekat pada suatu berita sebagai pelengkap dan penguat pesan yang disampaikan dalam berita (Yunus, 2010).

Jadi, fotografi jurnalistik adalah kegiatan fotografi yang bertujuan merekam jurnal peristiwa-peristiwa yang menyangkut manusia. Definisi fotografi jurnalistik dapat diketahui dengan menyimpulkan ciri-ciri yang melekat dalam foto yang dihasilkan. Dengan demikian, fotografi jurnalistik adalah salah satu teknik atau seni yang terekam, diabadikan, dan menceritakan suatu peristiwa. Foto jurnalistik menembus sekatsekat dalam kehidupan nyata, menunjukkan ada sesuatu yang terlihat, sesuatu yang nyata yang ingin disampaikan kepada khalayak.

\section{Komunikasi Visual}

Pada prinsipnya komunikasi visual merupakan perancangan untuk menyampaikan pola pikir dari penyampaian pesan dari komunikator kepada komunikan melalui penggunaan media penggambaran yang hanya terbaca oleh indera penglihatan. Pesan yang disampaikan bisa berupa bentuk visual yang komunikatif, terpola, terpadu, efektif, dan tepat melalui media tertentu sehingga dapat menyampaikan informasi dan mengubah sifat positif dari sasarannya.

Informasi akan berguna apabila dikomunikasikan kepada orang dalam bentuk yang dapat dimengerti dan direpresentasikan secara logis dan konsisten. Sebagai sarana representasi dan promosi untuk menyampaikan pesan, mendapatkan perhatian (atensi) dari mata (secara visual), dan membuat pesan tersebut dapat diingat; contohnya foto. Juga sebagai sarana identifikasi. Identitas seseorang dapat mengatakan tentang siapa orang itu, atau dari mana asalnya.

Komunikasi visual atau bisa juga bahasa visual merupakan studi aplikasi atas semantik yang merupakan turunan dari akarakar filosofis yang sama halnya dengan linguistik. Namun bahasa atau kode lisan atau tulisan yang menggunakan bahasa visual 
membentuk komunikasi yang dikembangkan dalam semantik produk dan simbol visual, yaitu garis, warna, tekstur, rupa, dan bentuk yang bisa ditampilkan melalui foto, video, poster, baliho, dan sebagainya (Vihma Susann \& Seppo, 2009).

\section{Objektivikasi Perempuan dalam Fotografi} Jurnalistik

Objektivikasi dalam fotografi terhadap sosok perempuan bisa diartikan suatu kegiatan menjadikan perempuan sebagai sebuah perkara yang penting untuk menjadi pokok pikiran, sasaran, tujuan, pelengkap atau tujuan eksploitasi. Objektivikasi terjadi, ketika seseorang, melalui sarana-sarana sosial direndahkan derajatnya, dijadikan benda atau komoditas, dibeli atau dijual (Syarifah, 2006).

Berdasarkan teori objektivikasi, tubuh perempuan dianggap sebagai objek untuk dilihat dan dievaluasi. Budaya masyarakat yang mengobjekkan tubuh perempuan, menyosialisasikan perempuan untuk mempertontonkan dirinya sebagai objek yang dievaluasi atas dasar penampilan. Perempuan selalu dikondisikan dan diposisikan sebagai satu hal yang menarik.

\section{Feminisme}

Feminisme adalah sebuah gerakan perempuan yang menuntut emansipasi atau kesamaan dan keadilan hak dengan pria. Feminisme berasal dari bahasa Latin, femina atau perempuan. Istilah ini mulai digunakan pada tahun 1890-an, mengacu pada teori kesetaraan laki-laki dan perempuan serta pergerakan untuk memperoleh hak-hak perempuan. Sekarang ini kepustakaan internasional mendefinisikannya sebagai pembedaan terhadap hak hak perempuan yang didasarkan pada kesetaraan perempuan dan laki laki (Rosemarie Tong, 1997).
Menurut Humm (2007), feminisme menggabungkan doktrin persamaan hak bagi perempuan yang menjadi gerakan yang terorganisasi untuk mencapai hak asasi perempuan, transformasi sosial yang bertujuan untuk menciptakan dunia bagi perempuan. feminisme merupakan ideologi pembebasan perempuan dengan keyakinan bahwa perempuan mengalami ketidakadilan karena jenis kelaminnya. Feminisme menawarkan berbagai analisis mengenai penyebab, pelaku dari penindasan perempuan.

Feminisme didefinisikan secara beragam, mulai dari pergerakan untuk menyelamatkan hak-hak wanita sampai semua bentuk usaha penekanan. Para ahli suka membahas feminisme secara plural daripada secara singular. Para ahli feminisme memulainya dengan fokus pada gender dan mencari perbedaan antara seks - sebuah kategori biologis - dan gender - sebuah konstruksi sosial. Feminisme lebih dari sekadar menawarkan teori-teori yang memusatkan pada pengalaman wanita dan untuk membicarakan hubungan antara kategori-kategori gender dan sosial lainnya, termasuk ras, etnik, kelas, dan seksualitas (Littlejohn, 2011).

\section{Semiotika Roland Barthes}

Semiotika adalah ilmu yang mempelajari sistem tanda atau teori tentang pemberian tanda. Semiotik biasanya didefinisikan sebagai teori filsafat umum yang berkenaan dengan produksi tanda-tanda dan simbol-simbol sebagai bagian dari sistem kode yang digunakan untuk mengomunikasikan informasi. Semiotika meliputi tanda-tanda visual dan verbal (semua tanda atau sinyal yang bisa diakses dan bisa diterima oleh seluruh indera yang kita miliki), ketika tanda-tanda tersebut membentuk sistem 
kode yang secara sistematis menyampaikan informasi atau pesan secara tertulis di setiap kegiatan dan perilaku manusia.

Semiotika adalah studi mengenai tanda (sign) dan simbol yang merupakan tradisi penting dalam pemikiran tradisi komunikasi. Tradisi semiotika mencakup teori utama mengenai bagaimana tanda mewakili objek, ide, situasi, keadaan, perasaan, dan sebagainya yang berada di luar diri. Studi ini tidak saja memberikan jalan atau cara dalam mempelajari komunikasi tetapi juga memiliki efek besar pada setiap aspek (perspektif) yang digunakan dalam teori komunikasi (Morissan, 2013).

Semiotika ini merupakan salah satu tradisi dalam ilmu komunikasi yang menganggap bahwa fenomena sosial atau masyarakat dan kebudayaan itu merupakan tanda-tanda, konvensi-konvensi yang memungkinkan tandatanda atau simbol-simbol tersebut mempunyai arti atau makna. Menurut Charles S. Peirce dalam Fiske (1990) dan Littlejohn (2011), semiotika berangkat dari tiga elemen utama, yakni teori segi tiga makna atau triangle meaning. Yang dikupas dalam teori segi tiga ini adalah persoalan bagaimana makna muncul dari sebuah tanda ketika tanda itu digunakan orang pada waktu berkomunikasi (Kriyantono, 2012).

Berikut tabel hubungan tanda, objek, dan interpretant (triangle of meaning).

Tabel 1. Triangle of Meaning

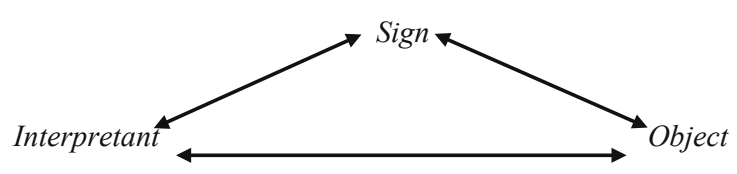

Sumber: Kriyantono (2012)

a. Tanda adalah sesuatu yang berbentuk fisik yang dapat diungkap oleh panca indera manusia dan merupakan sesuatu yang merujuk (merepresentasikan) hal lain di luar tanda itu sendiri. Acuan tanda ini disebut objek.

b. Acuan tanda (objek) adalah konteks sosial yang menjadi referensi tanda atau suatu yang dirujuk tanda.

c. Pengguna tanda (interpretant) adalah konsep pemikiran dari orang yang menggunakan tanda dan menurunkannya ke suatu makna tertentu atau makna yang ada dalam benak seseorang tentang objek yang dirujuk sebuah tanda.

Semiotika atau penyelidikan simbolsimbol membentuk tradisi pemikiran yang penting dalam teori komunikasi. Tradisi semiotik terdiri atas sekumpulan teori tentang bagaimana tandatanda merepresentasikan benda, ide, keadaan, situasi, perasaan, dan kondisi di luar tanda-tanda itu sendiri (Littlejohn dan Foss, 2011).

Pemikiran Saussure yang paling penting dalam konteks semiotik adalah pandangannya mengenai tanda. Saussure meletakkan tanda dalam konteks komunikasi manusia dengan melakukan pemilihan antara apa yang disebut signifier (penanda) adalah bunyi yang bermakna atau coretan yang bermakna (aspek material), yakni apa yang dikatakan dan apa yang ditulis atau dibaca. Signified (petanda) adalah gambaran mental, yakni pikiran atau konsep aspek mental dari bahasa. Saussure menggambarkan tanda yang terdiri atas signifier dan signified itu dalam bentuk tabel sebagai berikut.

Tabel 2. Elemen-Elemen Makna Saussure

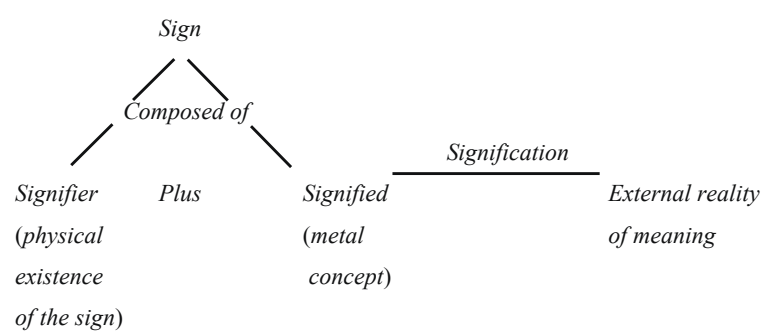

Sumber: Sobur (2009) 
Roland Barthes dikenal sebagai salah seorang pemikir strukturalis yang getol mempraktikkan model linguistik dan semiologi Saussure. Ia juga seorang intelektual dan kritikus sastra Prancis yang ternama; eksponen penerapan strukturalisme dan semiotika pada studi sastra. Barthes meneruskan pemikiran Saussure tersebut dengan menekankan interaksi antara teks dengan pengalaman personal dan kultural penggunanya, interaksi antara konvensi dalam teks dengan konvensi yang dialami dan diharapkan oleh penggunanya. Gagasan Barthes ini dikenal dengan "order of significations".

Sementara itu, objek adalah sesuatu yang menjadi referensi dari tanda. Sementara interpretant adalah tanda yang ada dalam benak seseorang tentang objek yang dirujuk sebuah tanda. Peirce membagi tanda atas icon (ikon), index (indeks), dan symbol (simbol). Ikon adalah tanda yang hubungan antara signifier dan signified bersifat bersamaan bentuk alamiah. Atau dengan kata lain, ikon adalah hubungan antara tanda dan objek atau acuan yang bersifat kemiripan. Indeks adalah tanda yang menunjukkan adanya hubungan alamiah antara signifier dan signified yang bersifat kausal atau hubungan sebab akibat, atau tanda yang langsung mengacu pada kenyataan. Tanda dapat pula mengacu ke denotatum melalui konvensi.

Semiotika dalam penelitian ini menggunakan pendekatan melalui gagasan signifikasi dua tahap Roland Barthes (two order of signification). Semiotika mengasumsikan pesan medium tersusun atas seperangkat tanda untuk menghasilkan makna tertentu. Makna tersebut bukanlah innate meaning (makna bawaan alamiah), melainkan makna yang dihasilkan oleh sistem perbedaan atau hubungan tanda-tanda. Barthes menciptakan peta tentang bagaimana tanda bekerja (Sobur, 2009).
Tabel 3. Peta Tanda Roland Barthes

\begin{tabular}{|c|c|c|}
\hline 1. Signifier & 2. Signified & \\
\hline \multicolumn{3}{|c|}{ 3. Denotative Sign } \\
\hline 4. Conotativ & ignifier & $\begin{array}{l}\text { 5. Conotative } \\
\text { Signified }\end{array}$ \\
\hline
\end{tabular}

Sumber: Sobur (2009)

Penelitian ini menganalisis lima karya foto jurnalistik dalam pameran "Jalan Menuju Media Kreatif \#8" dengan menggunakan analisis semiotika model Roland Barthes yang melalui tahapan Analisis Leksia dan Kode Pembacaan.

Analisis Leksia

Leksia dipilih dan ditentukan berdasarkan pada kebutuhan pemaknaan yang akan dilakukan. Pada gambar, leksia biasanya didasarkan pada satuan tanda-tanda (gambar) yang dianggap penting dalam pemaknaan.

Kode Pembacaan

Bagi Roland Barthes, di dalam teks beroperasi lima kode pokok (ice major code) terdiri dari kode hermeneutika, kode proairetik, kode simbolik, kode kultural, dan kode semik.

\section{PEMBAHASAN}

Analisis Foto 1

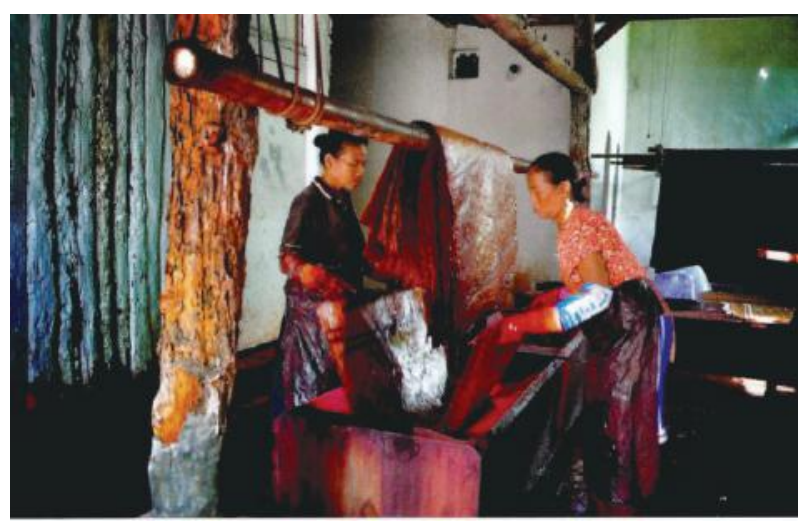

Foto karya Ang Giok Bing judul "Mencuci" Sumber: Katalog pameran Jalan Menuju Media kreatif \#8 hlm. 62 
Identifikasi Kode Foto Perempuan berjudul

"Mencuci" karya Ang Giok Bing

\begin{tabular}{ll}
\hline \multicolumn{1}{c}{ Signified (Penanda) } & \multicolumn{1}{c}{ Signifier (Penanda) } \\
\hline Pengambilan gambar & Full Shot \\
Sudut pandang & Eye Level Angle \\
Pencahayaan & High Contras \\
\hline Pewarnaan & Warm \\
\hline
\end{tabular}

Analisis Leksia

1. Dua orang perempuan sedang berdiri saling berhadapan.

2. Keduanya bekerja sama mencuci kain batik.

3. Tangan dari kedua perempuan itu terbungkus kain tebal hingga siku.

4. Rambut dari kedua perempuan diikat di bagian belakang kepala

5. Kedua perempuan dilingkar pinggangnya hingga ke bawah dilapisi plastik.

6. Penampilan kedua perempuan ini sangat natural dan tanpa mengenakan make up

7. Latar belakang dari foto ini sebuah dinding yang sebagian terbuat dari tembok batu bata lengkap dengan plesteran halus dan sebagian lagi berupa dinding kayu.

\section{Kode Pembaca}

1. Kode Hermeneutika

Mengapa dua orang perempuan itu berdiri dan saling berhadapan? Mengapa keduanya bekerja sama? Mengapa tangan kedua perempuan itu dibungkus kain hingga siku? Mengapa pinggang dari kedua perempuan itu dibalut plastik hingga mata kaki? Mengapa rambut kedua perempuan itu sama-sama diikat di bagian belakang kepala? Mengapa kedua perempuan itu tanpa make up?

\section{Kode Proairetik}

Posisi kedua perempuan yang berdiri saling berhadapan dan bekerja sama menunjukkan dewi tunggal yang saling membutuhkan untuk menyelesaikan satu tanggung jawab. Tangan yang terlindung oleh kain dan pelapis plastik yang melindungi batas pinggang hingga atas mata kaki kedua perempuan ini merepresentasikan sikap selalu hatihati kaum perempuan dalam menjalani kehidupan. Sementara itu, kedua perempuan ini tampil tanpa make up menunjukkan kesan alami, pekerja keras, sederhana, dan pada dasarnya perempuan siap ditempatkan di posisi apa pun dalam pekerjaan.

3. Kode Simbolik

Rambut yang diikat di bagian belakang kepala ini menunjukkan bahwasanya kaum perempuan ini pandai menyembunyikan segala apa yang dirasakan, rasa sakit tanpa harus menutupnutupi dengan hal lain. Rambut perempuan yang diikat dalam foto ini dipandang sebagai simbol sebagai subordinasi kaum laki-laki. Ikatan rambut perempuan menunjukkan bahwa perempuan ini terbatas kebebasan dan ruang geraknya sehingga seolah-olah terkungkung oleh laki-laki.

4. Kode Kultural

Kedua perempuan dalam foto mengenakan baju yang berbeda, satu perempuan mengenakan kaos berkerah sedangkan yang satu mengenakan baju bermotif batik. Dari kedua jenis baju yang berbeda seolah menunjukkan budaya yang berbeda, yaitu budaya Barat dan Timur. Akan tetapi, kedua perempuan ini 
berwajah khas Asia. Aktivitas mencuci kain batik ini juga menggambarkan ciri identik perempuan Asia. Hal ini karena batik memang lekat dengan budaya lokal Asia khususnya Indonesia.

5. Kode Semik

Saat ini perempuan dianggap sukses, istimewa, modern, hanya jika berpenampilan cantik, seksi, dan tampil bekerja di depan umum. Akan tetapi, berbeda dengan yang ditampilkan melalui foto karya Ang Giok Bing ini, perempuan diposisikan sebagai sosok pekerja keras, tahan banting, meskipun sudah usia setengah baya. Perempuan dalam foto ini tidak memedulikan penilaian dari kaum laki-laki yang biasanya hanya melihat kecantikan dan keseksian.

\section{Analisis Foto 2}

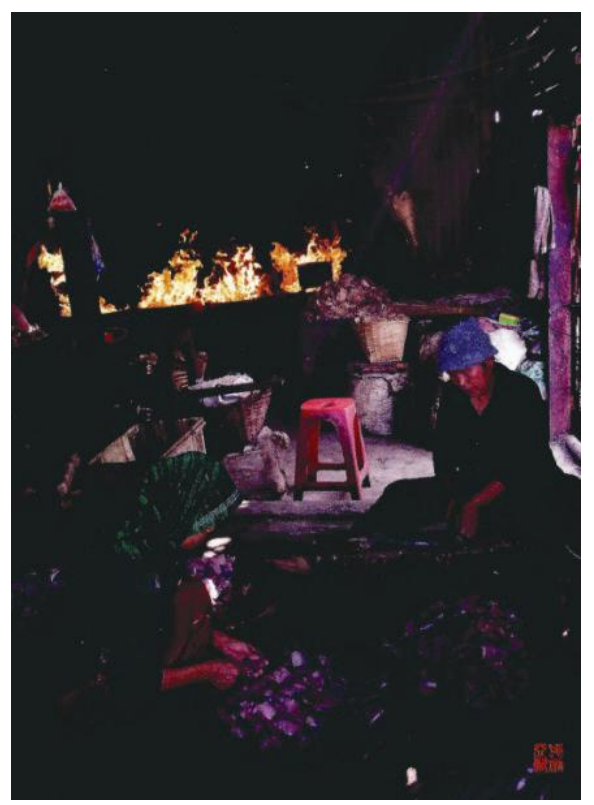

Foto karya Stephanus Setiawan judul "Pengasapan Ikan"

Sumber : Katalog pameran Jalan Menuju Media kreatif \#8 hlm. 64
Identifikasi Kode Foto Perempuan berjudul

"Pengasapan Ikan" karya Stephanus Setiawan

\begin{tabular}{ll}
\hline \multicolumn{1}{c}{ Signified (Penanda) } & \multicolumn{1}{c}{ Signifier (Penanda) } \\
\hline Pengambilan gambar & Long Shot \\
Sudut pandang & Bird Level Angle/High \\
& Angle \\
Pencahayaan & High Contras \\
\hline Pewarnaan & Dark \\
\hline
\end{tabular}

Analisis Leksia

1. Dua orang perempuan duduk saling berhadapan.

2. Satu perempuan memotong ikan, perempuan yang satunya menusuk potongan ikan.

3. Satu mengenakan jilbab dan mengenakan sarung, perempuan yang satunya mengenakan topi dan mengenakan celana panjang.

4. Kedua perempuan tampil tanpa make up.

5. Latar belakang foto kobaran api yang pemanggangan ikan.

Kode Pembaca

1. Kode Hermeneutika

Mengapa dua perempuan duduk saling berhadapan? Mengapa kedua perempuan melakukan aktivitas yang berbeda? Mengapa satu perempuan mengenakan jilbab, satunya mengenakan topi? Mengapa kedua perempuan tidak merias wajahnya?

2. Kode Proairetik

Perempuan yang saling duduk berhadapan dan melalukan pekerjaan yang berbeda, namun saling melengkapi. Perempuan mengenakan jilbab dan kain sarung menandakan seorang muslimah yang wajib menutup aurat. Perempuan mengenakan topi dan celana panjang 
menggambarkan perempuan yang bebas. Kedua perempuan dalam foto tidak mengenakan make up menandakan perempuan dengan pekerjaan mengasap ikan tidak mementingkan penampilan pada saat bekerja.

3. Kode Simbolik

Perempuan mengenakan jilbab diasosiasikan sebagai perempuan muslim yang religius, agamis, menjalankan syariat agama islam, dan merepresentasikan wanita anggun. Perempuan mengenakan topi diasosiasikan sebagai perempuan yang cenderung tidak mengabaikan simbol-simbol religi. Mengenakan celana panjang merupakan simbol yang bisa diasosiasikan sebagai perempuan tomboy, bisa bergerak lebih bebas, memiliki langkah yang lebih lebar. Latar belakang bara api merepresentasikan perih dan panasnya perjuangan kedua perempuan dalam foto ini untuk bisa bertahan hidup dengan pekerjaannya.

4. Kode Kultural

Penampilan perempuan yang mengenakan jilbab dikatakan sebagai seorang perempuan dengan keimanan dan keislamanyang sempurna. Perempuan yang bertopi dikatakan seorang perempuan yang kurang memahami pentingnya menutup aurat. Pada era modern seperti saat ini, tampaknya perempuan lebih memerhatikan inner beauty, sedangkan penampilan luar lebih cenderung diabaikan.

5. Kode Semik

Setiap orang menilai kecantikan perempuan itu dengan berbagai macam perspektif yang sangat subjektif. Namun definisi kecantikan bah sebagian besar orang pada umumnya sama, yaitu tinggi, langsing, putih, seksi, berambut panjang, dan sebagainya. Akan tetapi, dalam karya ini sosok perempuan ditampilkan dalam perspektif yang berbeda. Dalam karya ini perempuan tampil merepresentasikan sosok yang kuat, tahan panas, dan rajin. Dalam karya foto jurnalistik, foto ini menginformasikan berita bahwa perempuan itu tidak hanya tampil untuk dieksploitasi kecantikan, rambut panjangnya, kulit putihnya, dan make up tebalnya.

\section{Analisis Foto 3}

Identifikasi Kode Foto Perempuan berjudul "Smile" karya Ajie Lubis

\begin{tabular}{ll}
\hline \multicolumn{1}{c}{ Signified (Penanda) } & Signifier (Penanda) \\
\hline Pengambilan gambar & Close Up \\
Sudut pandang & Eye Level Angle \\
Pencahayaan & High Contras \\
\hline Pewarnaan & Bright \\
\hline
\end{tabular}

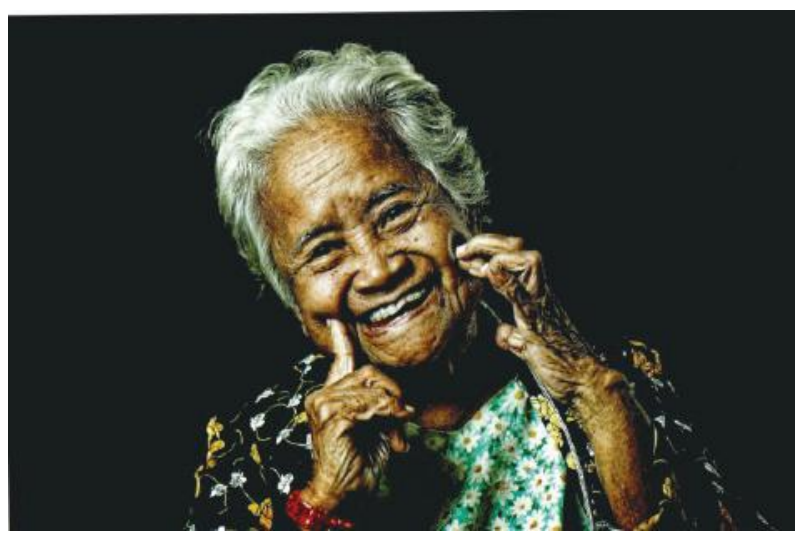

Foto karya Ajie Lubis judul "Smile" Sumber: Katalog pameran Jalan Menuju Media kreatif \#8 hlm. 66 


\section{Analisis Leksia}

1. Seorang perempuan berpose tersenyum dengan kepala agak miring.

2. Kedua jari tangan kanan dan kirinya ditempelkan ke pipi.

3. Ia mengenakan baju bercorak batik dan bunga-bunga.

4. Model ini mengenakan gelang tangan warna merah.

5. Rambutnya putih lekat merata.

6. Wajahnya tampil tanpa make up.

\section{Kode Pembaca}

\section{Kode Hermeneutika}

Mengapa perempuan tersebut berpose tersenyum dengan memiringkan kepala? Mengapa jari telunjuknya ditempelkan di kedua pipinya? Mengapa perempuan tersebut mengenakan baju bermotif batik? Mengapa model ini mengenakan gelang tangan warna merah? Mengapa tampil tanpa make up?

2. Kode Proairetik

Perempuan berpose tersenyum
menunjukkan sebuah kebebasan,
sedangkan memiringkan kepala bisa
diartikan tidak terkekang oleh batasan-
batasan. Jari tangan yang menempel di
kedua pipinya menandakan ekspresi
model yang tetap terkesan eksotis.
Meskipun sudah keriput, ia ingin tetap
terlihat menarik karena ini merupakan foto
jurnalistik. Gelang tangan warna merah
menandakan bahwa untuk tampil modis
tidak berarti hanya untuk perempuan
muda. Kulit keriput dan rambut putih lekat
menandakan suatu keadaan yang tidak bisa
dihindarkan oleh setiap manusia. Model
ditampilkan tanpa make up menandakan
keaslian seorang perempuan dengan detail-
detail keriput perempuan Indonesia.

Perempuan berpose tersenyum menunjukkan sebuah kebebasan, sedangkan memiringkan kepala bisa batasan. Jari tangan yang menempel di kedua pipinya menandakan ekspresi Meskipun sudah keriput, ia ingin tetap terlihat menarik karena ini merupakan foto jurnalistik. Gelang tangan warna merah menandakan bahwa untuk tampil modis tidak berarti hanya untuk perempuan muda. Kulit keriput dan rambut putih lekat menandakan suatu keadaan yang tidak bisa ditampilkan tanpa make up menandakan detail keriput perempuan Indonesia.

\section{Kode Simbolik}

Penggunaan gelang tangan warna merah diasosiasikan sebagai perempuan tua yang tetap modis. Senyum model perempuan tua merepresentasikan kebebasan menjalani masa-masa usia tua, tanpa memikirkan beban kehidupan. Baju batik bagian dalam berwarna lebih cerah dan bermotif bungabunga merepresentasikan suasana batin yang gembira dan tenang. Baju bagian luar yang motif batik dengan warna gelap menggambarkan keaslian usia yang tidak bisa ditutupi lagi penampilan fisiknya. Jadi, model perempuan tua ini merepresentasikan seseorang yang sudah tua, tetapi tetap bahagia dengan penampilan yang tetap modis.

4. Kode Kultural

Perempuan dengan wajah khas Indonesia dan tampil tanpa make up menunjukkan bahwa model ingin tampil apa adanya tanpa harus menutupi keaslian wajah keriputnya. Baju motif batik menunjukkan model perempuan tua ini menunjukkan bahwa batik merupakan warisan budaya Indonesia. Gelang tangan warna merah menunjukkan salah satu hasil akulturasi budaya Indonesia dan budaya dari luar/asing.

5. Kode Semik

Meskipun hingga saat ini perempuan dikatakan cantik dengan salah satu kriterianya adalah masih muda oleh sebagian besar laki-laki, lain halnya dengan karya foto jurnalistik yang satu ini. Fotografer menampilkan sosok perempuan yang berbeda dari kebanyakan. Fotografer melalui karyanya ingin menampilkan seorang perempuan tua yang tetap memiliki daya tarik dengan senyum, keaslian, dan tetap modis untuk menggambarkan arti kebebasan yang sebenarnya. 


\section{Analisis Foto 4}

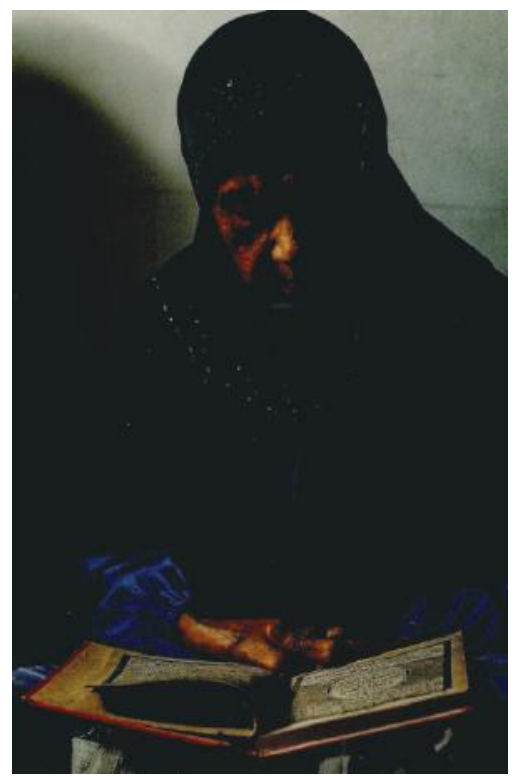

Foto karya John Tefon judul "Khusuk" Sumber: Katalog pameran Jalan Menuju Media kreatif \#8 hlm. 67

Identifikasi Kode Foto Perempuan berjudul "Khusuk" karya John Tefon

\begin{tabular}{ll}
\hline \multicolumn{1}{c}{ Signified (Penanda) } & \multicolumn{1}{c}{ Signifier (Penanda) } \\
\hline Pengambilan gambar & Medium Close Up \\
Sudut pandang & Eye Level Angle \\
Pencahayaan & High Contras \\
\hline Pewarnaan & Dark \\
\hline
\end{tabular}

Analisis Leksia

1. Seorang perempuan duduk bersimpuh menunduk.

2. Tangan disatukan di depan dan jarijarinya saling mengait.

3. Model mengenakan kerudung warna hitam dan berbaju warna biru.

4. Tepat di depan model perempuan sebuah kitab suci Alquran yang diletakkan di atas tas.

5. Wajahnya tampil tanpa make up.
Kode Pembaca

1. Kode Hermeneutika

Mengapa model duduk bersimpuh dan menunduk? Mengapa tangannya disatukan di depan dan jarinya saling mengait? Mengapa model mengenakan kerudung warna hitam dan baju warna biru? Mengapa model menyimak kitab suci Alquran? Mengapa model tidak mengenakan make up?

2. Kode Proairetik

Pose menunduk menunjukkan sifat perempuan yang pemalu dan menjadi subordinasi laki-laki. Pakaian yang rapat dengan menutup aurat menandakan model adalah wanita muslim. Tepat di depan model ada sebuah Alquran yang terbuka halamannya menandakan model sedang membaca salah satu surat atau ayat yang ada di dalamnya. Kedua tangan yang jarinya saling terkait menandakan model sedang konsentrasi membaca. Tampil tanpa make up ini menunjukkan bahwa dalam agama Islam tidak boleh berlebih-lebihan dalam penampilan.

3. Kode Simbolik

Warna kerudung hitam dan baju biru dapat diasosiasikan model pada saat mengaji itu jiwanya menjadi adem, damai, dan tenang. Pose model yang merunduk dan jari-jari tangannya saling terkait merepresentasikan suasana yang khusyuk seperti dalam judul foto yang disematkan oleh fotografer, yaitu "Khusuk". Alquran yang diletakkan di atas sebuah tas dapat diartikan bahwa untuk membaca Alquran tidak harus menggunakan alas khusus. Daam situasi apa pun model merepresentasikan 
tidak ada beban dalam membacanya. Keseluruhan foto yang ditampilkan oleh fotografer terlihat agak gelap, akan tetapi masih ada sisi terangnya. Hal ini merepresentasikan bahwa kitab suci Alquran yang diturunkan membawa dari kegelapan kepada kecerahan.

4. Kode Kultural

Model perempuan banyak digambarkan pada stereotipe yang harus tampil cantik, berambut panjang, berkulit putih, dan berpose seksi. Hal semacam ini menjadi kebalikan dalam perspektif agama Islam. Dalam agama Islam perempuan dituntut untuk menutup auratnya yang hampir menutupi seluruh tubuhnya, hanya bagian teman dan wajah yang boleh terlihat. Perempuan tidak perlu menuntut kesejajaran dengan laki-laki yang auratnya hanya sebatas pusar hingga bawah lutut. Semua ini karena dalam kultur agama Islam sudah diatur dan dijelaskan, perempuan itu sudah dimuliakan posisinya dengan bentuk penghormatan menempati tiga posisi paling utama untuk dihormati. Sementara itu, membaca kitab suci Alquran dalam agama Islam itu menjadi suatu hal yang tidak boleh dipisahkan dalam kehidupan sehari-hari.

5. Kode Semik

Sejak kecil dalam agama Islam sudah ada pembeda bagi anak laki-laki dan anak perempuan. Anak laki-laki dididik menjadi sosok yang kuat dan bertanggung jawab, sedangkan anak perempuan cenderung dididik untuk menjadi penurut, lebih banyak diam di satu tempat, dan penyabar.

\section{SIMPULAN}

"Jalan Menuju Media Kreatif \#8" ini merupakan salah satu pameran seni dari sekian banyak pameran seni yang ada di Yogyakarta. Pameran menjadi sarana ekspresi para seniman fotografi, fotografer profesional, dan pelaku seni di seluruh penjuru Indonesia bahkan dunia. Untuk mewadahi itu semua Fakultas Seni Media Rekam, ISI Yogyakarta membuat agenda pameran rutin, yaitu "Jalan Menuju Media Kreatif".

Berdasarkan hasil pengamatan dan analisis pada foto-foto jurnalistik dalam katalog pameran "Jalan Menuju Dunia Kreatif \#8" tahun 2016, keempat perempuan yang ditampilkan oleh empat fotografer profesional ini mengambil perspektif yang sangat berbeda dari kebanyakan. Perempuan tidak diposisikan sebagai objek keindahan untuk dilihat, diamati, dan dievaluasi hanya sebagai bahan eksplorasi yang disajikan untuk para penikmat fotografi dan para pengunjung pada saat pameran berlangsung. Keempat foto jurnalistik tersebut membawa muatan sosial dan kultural masyarakat Asia.

Keberanian fotografer yang bisa dibilang anti-mainstream dalam menampilkan karya dengan menghadirkan perempuan tua, perempuan tradisional, dan tanpa make up sedikit pun menjadi nilai lebih dalam karya fotografi jurnalistik. Pertama foto-foto tersebut tampil tidak lagi membawa perempuan yang langsing, cantik, berkulit putih, dan berambut panjang, dengan begitu foto ini hadir mencoba menampik konstruksi yang sering dibangun oleh kaum laki-laki terhadap perempuan. Kemudian yang kedua, sosok perempuan yang rajin dan piawai mengerjakan pekerjaan tidak hanya menyoal pekerjaan wilayah domestik perempuan. 
Objektivitas perempuan dalam karya foto jurnalistik ini terjadi pada; pertama, objektivitas perempuan terletak pada kecantikan inner beauty, bukan hanya pada fisik semata. Objektivitas keduaadalah perempuan dalam foto ini cenderung menikmati pekerjaannya sebagai ibu rumah tangga dan tidak menghiraukan dunia luar yang menuntut tampil sempurna. Objektivitas ketiga adalah perempuan tampil apa adanya tanpa menonjolkan make up tebal, cantik, kulit putih, dan rambut panjangnya.

Mitos kecantikan dalam foto-foto jurnalistik ini tidak lagi menjadi seperti yang banyak ditampilkan di berbagai media massa, baik cetak maupun elektronik. Dari keempat foto yang dianalisis, fotografer menempatkan mitos kecantikan perempuan terletak lebih pada inner beauty perempuan itu sendiri. Kecantikan dalam foto-foto ini disajikan melalui keaslian wajah, profesi, dan ketaatannya. Mitos lain yang terdapat pada foto-foto ini adalah mitos penempatan perempuan yang selalu di wilayah domestik. Terdapat anggapan yang beredar di masyarakat bahwa perempuan seharusnya berada di rumah dan mengurus keperluan rumah tangga. Dengan demikian, perempuan tidak lagi hanya menghabiskan waktunya untuk berdandan dan bergaya saja.

Terkait dengan feminisme, dalam fotofoto yang dipamerkan dalam pameran "Jalan Menuju Media Kreatif \#8" ini perempuan cenderung melakukan kegiatan-kegiatan yang ada pada dirinya (kodrat perempuan). Kegiatan tersebut bukanlah suatu keterpaksaan perempuan yang dipandang sebagai subordinasi laki-laki. Akan tetapi, kegiatan-kegiatan yang dilakukan perempuan dalam foto-foto tersebut merupakan kegiatan yang sudah ditanamkan secara turun-temurun.

\section{KEPUSTAKAAN}

Bungin, B. (2008). Konstruksi Sosial Media Massa: Kekuatan Pengaruh Media Massa, Iklan Televisi dan Keputusan konsumen serta Kritik Terhadap Peter Berger \& Thomas Luckmann. Jakarta: Kencana Prenada Media Group.

Fiske, J. (1990). Cultural and Communication Studies. New York: Routledge.

Humm, M. (2007). Ensiklopedia Feminisme. Yogyakarta: Fajar Pustaka Baru.

Kriyantono, R. (2012). Teknik Praktis Riset Komunikasi. Jakarta: Kencana Prenada Media Group.

Littlejohn, S. W. (2011). Theories of Human Communication. Jakarta: Salemba Humanika.

Morissan. (2013). Teori Komunikasi; Individu Hingga Massa. Jakarta: Kencana Prenada Media Group.

Partanto, P. \& Drahlan Al-Barry, M. (1994). Kamus Ilmiah Popular. Surabaya: Arkola. Rosemarie Tong. (1997). Feminist Thought: A Comprehensive Introduction. USA: Westview Press.

Sobur, A. (2009). Semiotika Komunikasi. Surabaya: Remaja Rosda Karya.

Syarifah. (2006). Kebertubuhan Perempuan dalam Pornogarfi. Jakarta: Yayasan Kota Kita.

Vihma Susann \& Seppo, V. (2009). Semotika Visual dan Semantika Produk. Yogyakarta: Jalasutra.

Yunus, S. (2010). Jurnalistik Terapan. Jakarta: Ghalia Indonesia. 